\title{
Evaluation of Thermal Comfort in the Traditional Bourgeoisie Houses in Beirut
}

\author{
Jad Hammoud $^{1} \&$ Elise Abi Rached ${ }^{2}$ \\ ${ }^{1}$ Faculty of Fine arts and Architecture, Lebanese University. Hadath Campus, Branch I, Beirut, Lebanon \\ ${ }^{2}$ Faculty of Fine arts and Architecture, Lebanese University. Furn El Chebbek, Branch II, Beirut, Lebanon \\ Correspondence: Jad Hammoud, Faculty of Fine arts and Architecture, Lebanese University. Hadath Campus, \\ Branch I, Beirut, Lebanon. E-mail: jadwhammoud@gmail.com, eliseabirached@hotmail.com
}

Received: December 13, 2019; Accepted: January 22, 2020; Published: March 5, 2020

\begin{abstract}
The increasing of energy demands has considerably increased the requirements for new and traditional buildings in different climate zones. Unprecedented heat waves have increased climate temperature, in particular, in moderate climate zones such as Lebanon. In Beirut, only the residential sector consumes $50 \%$ of total electricity consumption. HVAC (Heating, Ventilation and Air conditioning) systems are used to reach acceptable thermal comfort levels in the new residential buildings. In case of the traditional bourgeoisie houses in Beirut, there are no discussions about the use of HVAC systems to achieve the required thermal comfort level. Thus, to reach an acceptable thermal comfort level, these houses which already contain natural ventilation system shall adapt the modern thermal comfort requirements and thermal comfort strategies and technologies where their architectural features and existing materials condition the available solutions. In order to identify the best options within the possible intervention lines (envelopes, passive strategies, equipment, renewable energy systems), it is necessary to perceive the real performance of this type of houses. In this context, the article presents the results of the study of thermal performance and comfort in a three case studies located in Beirut. Detailed field data records collected are analyzed, with a view to identify the indoor thermal environment with respect to outdoor thermal environment in different seasons. Monitoring also included measurement of hygrothermal parameters and surveys of occupant thermal sensation.
\end{abstract}

Keywords: thermal performance, comfort assessment, monitoring, old buildings

\section{Introduction}

In the light of increasing the world energy-efficiency demand and the environmental awareness, several conventions are developed to reduce energy demands in the building sector including the historical ones such as 2030 energy strategy in the EU. In fact, buildings are a key sector to implement energy and environmental measures, since it is one of the largest energy and natural resources consuming sectors, responsible for a third of global total $\mathrm{CO}_{2}$ emissions. Dealing with energy saving in historical buildings requires certain regulations and practical researches for conserving their cultural significance and heritage value which was the reason behind issuing the first law in EU so called "Conservation of cultural heritage - Guidelines for improving the energy performance of historic buildings- EN16883" at the beginning of 2017. The Energy Performance of Buildings Directives (EPBD) and Energy Efficiency have set the EU targets of saving 20\% of primary energy consumption by 2020 and reducing greenhouse gas emissions by $80-95 \%$ by 2050 compared to 1990 levels. In Beirut, natural ventilation has not been studied or regulated by building designers to the housing stock built in the 1990s. Majority of its constructions rely on HVAC systems to provide thermal comfort inside the apartments, for which $40-44 \%$ of its energy consumption is consumed by HVAC. Residential buildings consume $65-73 \%$ of electrical energy production in Beirut and $80 \%$ if combined with commercial buildings. Therefore, to accomplish the targets, new high performance building concepts have been defined, as the zero-energy buildings, where energy demand must be reduced by renewable energy sources. Nevertheless, these actions are not always simple to implement in the existing building stock. Although, in the case of old buildings in Beirut, the links between the cultural heritages, thermal comfort and energy saving requirements are still missing, the diversity of traditional construction system, building materials and architectural features limit the range of available solutions. In order to achieve thermal comfort and a high-performance building inside the heritage buildings in Beirut and to choose the best design ventilation strategies for that building, it is very important to know the actual situation of the indoor environment 
concerning temperature and relative humidity and to reduce the energy demand for HVAC, by optimizing solar orientation and built form and by improving envelope's insulation levels. The most effective energy-refurbishing solution is frequently a combination of the best strategies that lead to a cost-optimal solution. So, for each building there is the need to identify the best solutions within the possible actions (envelope; passive strategies; equipment, renewable energy systems). With this information is possible to perceive how they can be improved to meet the new requirements of energy and thermal performance, and optimize the intervention. In this sense, this paper aims to contribute to the research field presenting the results of the study of thermal performance and comfort in a set of case studies located in Beirut. The study included an investigation for the thermal comfort in natural ventilated surveyed buildings and measurement of hygrothermal parameters on occupant thermal sensation. Moreover, data obtained will be compared with ASHRAE standard \& building ventilation strategies.

\section{Geographic Location and Climate Aspects}

Lebanon is located on the eastern shore of the Mediterranean Sea. It borders the Sea in the west, Syria in the north and east, and Palestine in the south. Its surface is 10,452 square kilometers, but small parts of the borders with Syria and Palestine are contested. Beirut is the largest city and the capital of Lebanon, located on the Mediterranean coast at the foot of Lebanon Mountains. The cape of Beirut, on the border of Mediterranean sea, is distinguished by its topographic complex marked by the presence of two hills which culminate at $100 \mathrm{~m}$ as altitude, one at Ashrafiyeh (East Beirut) and the other at Tallet al-Khayat or Moușsayțbeh (West Beirut), that protrude into the sea as a roughly triangular peninsula (Fig.1). As altitude is obviously one of the most important parameters that has an impact on dry-bulb temperature of a region and on the resulting thermal envelope energy requirements of a building, it was used as an indicator to draw a first outline of the climatic region (Fig.2 and Table 1). Beirut has a semitropical climate that is cool temperate in winter and hot and humid in summer. In January, the coolest month, the average afternoon maximum temperature is $17^{\circ} \mathrm{C}$, and the nighttime low is $11^{\circ} \mathrm{C}$. Comparable maximum and minimum temperatures in July are 31 and $23^{\circ} \mathrm{C}$. The rainy season extends from mid-autumn to early spring, and the average annual rainfall is $914 \mathrm{~mm}$ (Dubertret, L., \& Laferrère, M. 1956).

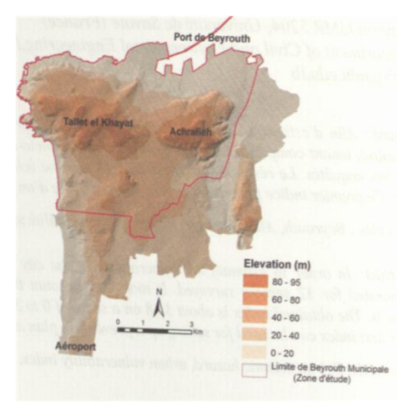

Figure 1. The climatic zone in Lebanon and mentioning Beirut in the red Circle (UNDP)

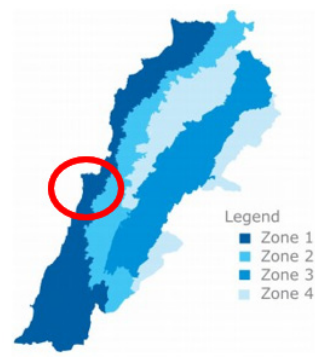

Figure 2. The topographic complex of Beirut (UNDP)

Table 1. UNDP Thermal Standards in Lebanon

\begin{tabular}{ccccc}
\hline \multirow{2}{*}{ LEGEND } & \multirow{2}{*}{ CLIMATIC REGIONS } & $\begin{array}{c}\text { MINIMUM } \\
\text { TEMPERATURE }\end{array}$ & $\begin{array}{c}\text { MAXIMUM } \\
\text { TEMPERATURE }\end{array}$ & $\begin{array}{c}\text { RELATIVE } \\
\text { HUMIDITY }\end{array}$ \\
\hline ZONE 1 & Coastal region & $7{ }^{\circ} \mathrm{C}-16{ }^{\circ} \mathrm{C}$ & $24^{\circ} \mathrm{C}-32{ }^{\circ} \mathrm{C}$ & $60 \%$ to $80 \%$ \\
ZONE 2 & Mid-mountain region & $0{ }^{\circ} \mathrm{C}-15{ }^{\circ} \mathrm{C}$ & $16^{\circ} \mathrm{C}-28^{\circ} \mathrm{C}$ & $40 \%$ to $60 \%$ \\
ZONE 3 & High-mountain region & $-7{ }^{\circ} \mathrm{C}-10^{\circ} \mathrm{C}$ & $15^{\circ} \mathrm{C}-30^{\circ} \mathrm{C}$ & $50 \%$ to $90 \%$ \\
ZONE 4 & Inland region & $-5{ }^{\circ} \mathrm{C}-15{ }^{\circ} \mathrm{C}$ & $15^{\circ} \mathrm{C}-40{ }^{\circ} \mathrm{C}$ & $30 \%$ to $75 \%$ \\
\hline
\end{tabular}

The wind data in Lebanon is less comprehensive than the temperature or humidity data. The "Atlas Climatique du Liban" provides the wind quantity (wind speed $\mathrm{x}$ time) and wind frequency observations. In general, we can say that in Lebanon, maritime air is blown from the sea September to May. It is a humid wind and most rain in Lebanon is caused by the humid air mass movement caused by these winds. In winter, continental air from north enters Lebanon through the internal valley which is mostly dry and cold and produces snow when mixed with warmer and humid maritime air. In summer, the air masses are warmer and slightly humid after their passage over the sea. The air masses have an effect on the natural infiltration in buildings that increases the heating and cooling loads which is important to consider in practice. In addition, there are two main causes of air motion through the building 
affecting the natural ventilation. First, the wind Force that strikes the building and creates a region of higher pressure on the windward side and a region of lower pressure like the leeward wall and roof. The pressure difference created across the building causes the air flow through the building from openings in the region of higher pressure to openings located in the region of lower pressure. Second, the thermal Force, when two openings are provided at different heights and the indoor temperature is higher than outdoors a difference in pressure is formed. Excess indoor pressure builds up at the upper opening, where air flows outwards, while a depression is created at the lower level, indicating an inward flow of air. When the indoor temperature is lower, the positions are interchanged and flow direction is reversed (Radha, C., \& Kistelegdi, I. 2016).

\section{Characteristics of Natural Ventilation System of the Beiruti Bourgeoisie Houses}

Natural ventilation is the controlled flow of air through doors, windows, vents, and other purposely provided openings caused by wind pressure. Natural ventilation is used when hygienic requirements for indoor air quality allow outdoor air supply without filtration and treatment and cannot be used when incoming out-door air causes mist or condensation. Though airflow through the building with natural ventilation is caused by both wind effect and buoyancy forces, Wind speed and direction can change over wide ranges and thus wind does not provide a stable force to move air through the building. Three case studies might be good example. Three Beiruti houses were selected at different locations, East, West and South of Beirut. The location of the three buildings are shown in figure 3. The distance between the buildings is between 1 and $2 \mathrm{~km}$. Their construction materials and architectural design are two factors to show the efficiency of thermal performance and the natural ventilation feasibility to provide comfort conditions. The interior spaces of the buildings are used for social activities that demand for natural ventilation, in contrast to thermal mass, and are an important strategy to integrate in such buildings. The exterior wall thickness was reduced and the window size was increased compared to houses before 1840s (Melki, H. 2013). A house's openings and windows are very important since people can enjoy fresh air in summer and the sun's warmth in winter.

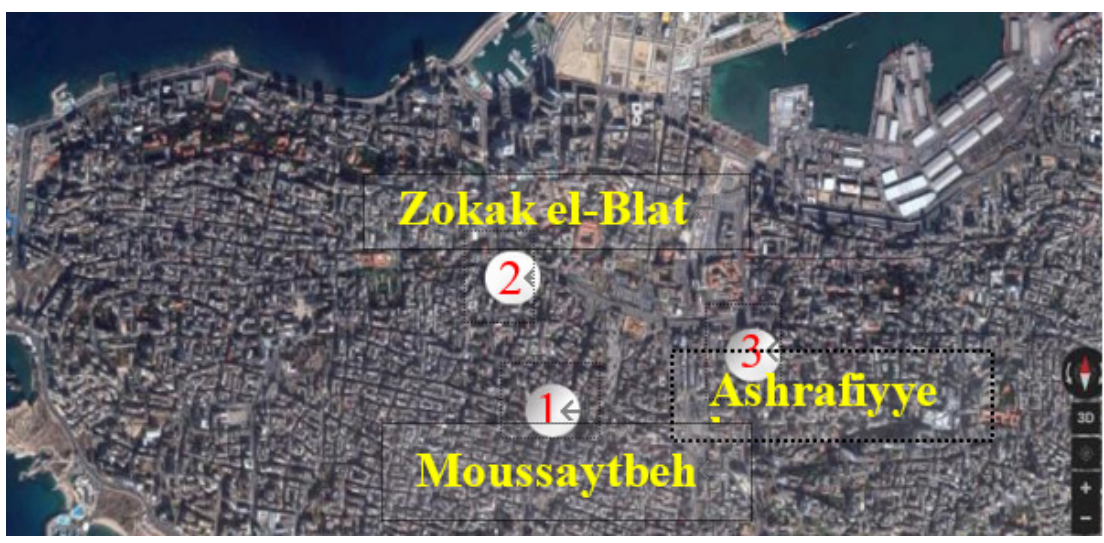

Figure 3. The location of the studied buildings(Google map 2017)

The importance of maintaining comfort through constant levels of temperature slowly gave way to criteria of view, natural ventilation with advantageous quality, solar gain and social activities while the thermal mass was no longer a priority. The solar gain and humidity are factors to consider on the coastal region. The supply of outside air to the interior for air motion for healthy and comfortable interior environment is generally defined as Ventilation. The role of natural ventilation is played as a passive cooling to achieve indoor air velocities having the appropriate temperature and humidity. Figures 4 and 5 show how a room is oriented. Windows are designed and located were maximum ventilation can occur in contrast to the high mountain region. They are wooden rectangular casement with wooden shutters from outside showing an evident size, form and function. They are sized to consist with the interior requirements as the cross-ventilation and to get the benefit of prevailing summer winds (Melki, H. 2013). The treatment of the wall in terms of surface area, thickness and materiality is a primary concern in relation to the design of the window. Smaller openings called qamariyyeh are placed near the top of the walls to allow warm air to escape. When glass sheets were widely used in the second half of the nineteenth century, the northern elevation was the best place to be widely open through a pointed triple arcades to allow light entrance and reveals greater solar gain. The existence of the three typologies was governed by criteria that nature imposed as well as the limitation of advanced technologies in the building industry; topography, solar exposure, humidity/precipitation and wind patterns all were taken into consideration. This was achieved through the many concepts of application; heavy masonry walls (thermal mass), solar exterior shading, ventilation, view, daylighting, etc, (Table $2 \& 3$ ). 
Table 2. Window/Wall Ratio - comparative analysis

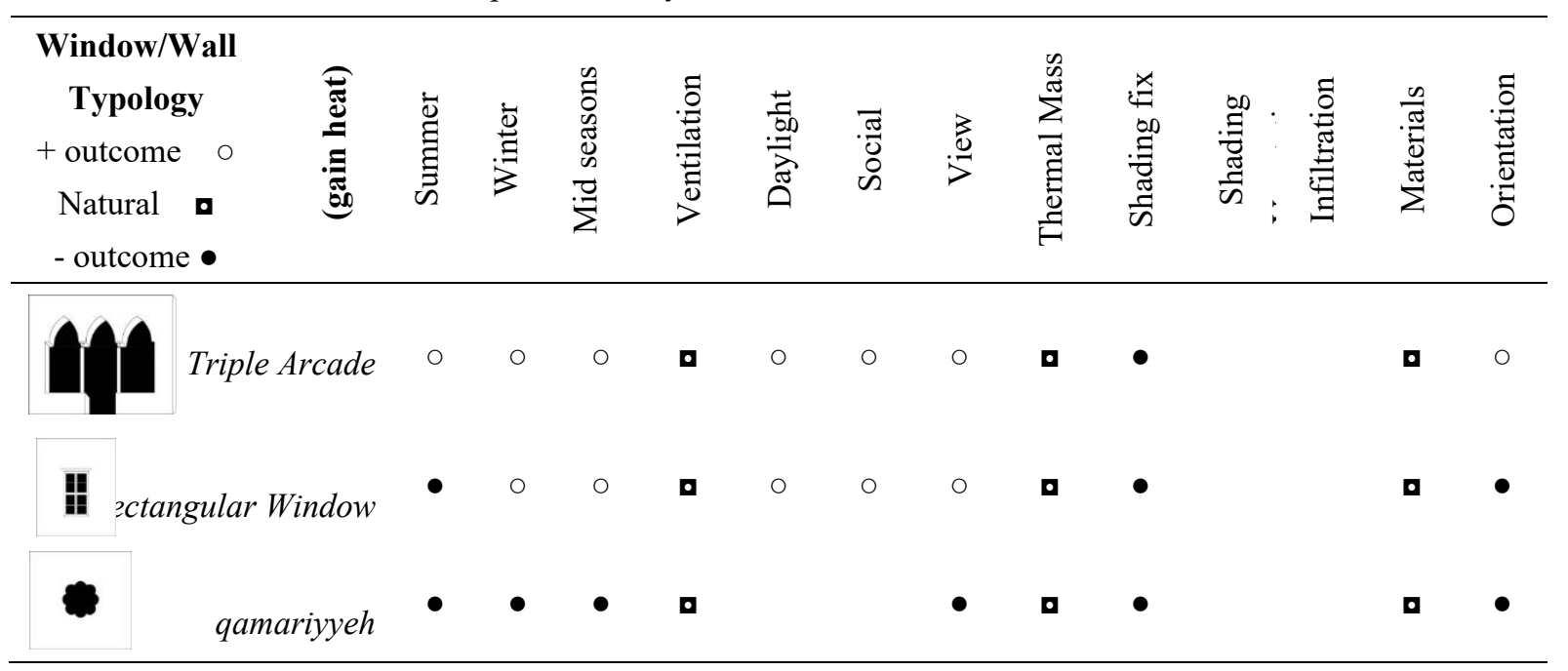

Table 3. Some dimensional and energetic indicators

\begin{tabular}{|c|c|c|c|c|}
\hline Buildings & $\begin{array}{l}\text { Area } \\
(\mathrm{m} 2)\end{array}$ & $\begin{array}{l}\text { Volume } \\
\text { (m3) }\end{array}$ & $\begin{array}{l}\text { Vertical } \\
\text { envelope } \\
(\mathrm{m} 2)\end{array}$ & $\begin{array}{l}\text { Vertical envelope to } \\
\text { windows area } \\
\text { ratio }(\%)\end{array}$ \\
\hline Building 1 (Taweel Building) & $240 \times 2=480$ & $2251+242=2493$ & 760 & $760 / 118=644 \%$ \\
\hline $\begin{array}{l}\text { Building } \underset{\text { Institut Beirut })}{\mathbf{2}}(\mathrm{OIB}, \text { Orient- } \\
\end{array}$ & $200+580+580=1360$ & $5984+209=6193$ & 1393 & $1393 / 143=974 \%$ \\
\hline Building 3 (Hatoum Building) & 240 & $1080+264=1344$ & 315 & $315 / 48=656 \%$ \\
\hline
\end{tabular}

As seen in figure 4, the entrance is through a side door facing east or west leading to the central hall, which is the living room during winter. This winter living room is surrounded by all the other rooms and so has no windows, which makes heating it in winter easy and quick. And there is no need to heat the rest of the house. In addition, closing the doors of the winter living room saves energy. All the rooms surround this central hall and its windows were placed according to sun orientation, topography, wind patterns, views and socio-cultural aspects. Windows are the least effective heat flow inhibitors of a building's shell. The windows show an evident size, form and function. The treatment of the wall in terms of surface area, thickness and materiality is a primary concern in relation to the design of the window. Windows are designed and sized to consist with the interior requirements as the cross-ventilation and to get the benefit of prevailing summer winds. The bedrooms are situated on either the east side or the west side, allowing the sun to penetrate deep into the rooms in the winter, when the sun is low. In summer, when the sun is higher, sunrays penetrate less, allowing the rooms to stay cooler. Devices such as wooden shutters had to be used in situations of excessive day lighting and direct solar exposure during the summer season. Windows and doors are facing each other, allowing fresh air to circulate between the rooms and lowering the interior temperature to a comfortable level. As the dominant winds in Lebanon blow toward the North- East, kitchens are generally situated on the South-East side of the house and less frequently on the South-West side with well-designed openings annoying cooking smells. Moreover, the walls with their traditional coating fight humidity, offer optimal insulation both in winter and summer. With no additional energy or financial cost, people can be comfortable living in the traditional Lebanese house, warm enough in the winter and cool in the summer. The liwan room of Taweel building has two windows facing each other in most houses. In summer, they allow for air movement and so the cool fresh air in the hot season becomes the new living room (Figure 5). 


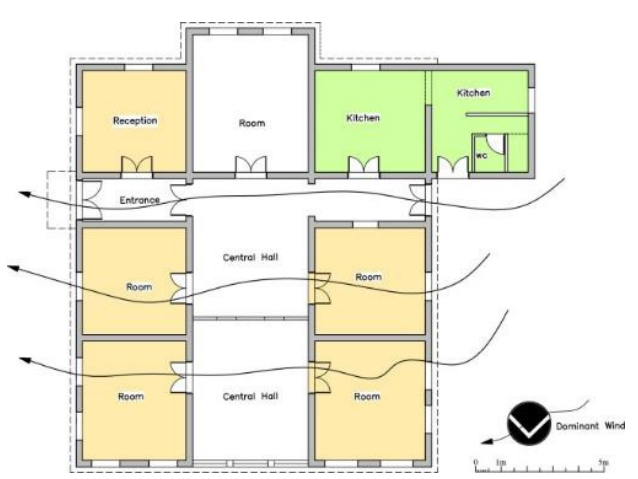

Figure 4. Ground Floor plan of Hatoum house located in Ashrafiyyeh, showing the design of openings where maximum ventilation can occur

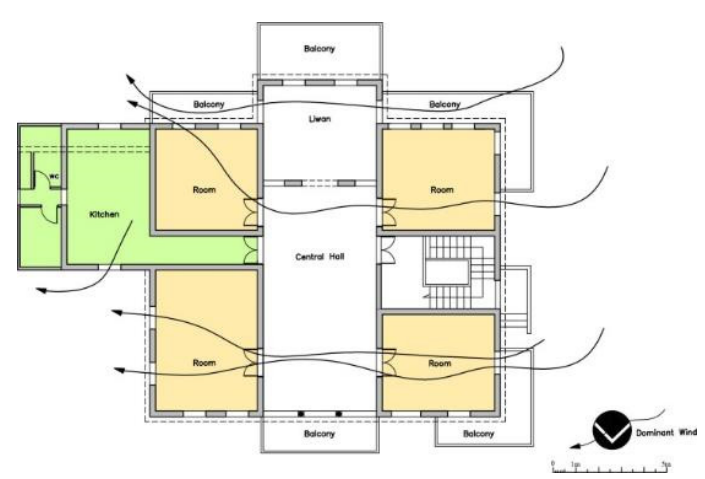

Figure 5. Ground Floor plan of Taweel house in Moussaytbeh (Hammoud J., 2017)

\section{Methodology}

The analysis of thermal performance and comfort assessment of three case studies for the Beiruti buildings in Beirut is essential and important to know the indoor and outdoor environment. In order to fulfill the objective, the research has adopted quantitative method which was carried out in the field to understand the thermal performance of traditional residential buildings with the same typology, built with the same building materials and in the same climatic zone. For this purpose, the analysis of thermal environment of buildings contains with field data monitoring of indoor thermal performance and comfort conditions of the case studies followed by discussion and aiming to draw the results. Assessing indoor thermal performance requires the division of short and long term monitoring that was carried every two months starting from November 2016. The assessment consisted of objective measurements that were performed with the purpose of quantitatively assessment of the thermal conditions within a specific room using a thermo-hygrometer sensors, Data Logger (Testo 174H) (Figure 6),

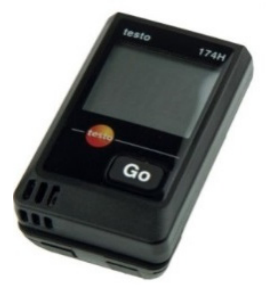

Figure 6. Data Logger instrument

in compliance with standards ISO EN 7726 and ISO EN 773. For the assessment of the thermal performance of each case study, thermo-hygrometer sensors were installed outdoors and indoors. The location of the sensors was chosen according to occupants' room selection taking into consideration the rooms that they spend more time in it. While the location of the Loggers installed outside were protected and not directed to sun, wind and rain. These sensors that measure the air temperature and relative humidity have a temperature accuracy of $\pm 0.5^{\circ} \mathrm{C}$, and a humidity accuracy of $\pm 3 \% \mathrm{rH}$ with recording data of $30 \mathrm{~min}$ intervals. The measurements were carried out during all seasons of the year, in compliance with specified procedures and standards (ISO EN 7726, ISO EN 7730, ASHRAE Standard 55). One of the objectives of this paper is to understand changes in air temperature and humidity by reading the occupancy records. Occupants fulfilled an occupancy table verifying how they used heating or cooling systems, promoted ventilation in the building. Other objective is to develop new equation to predict the indoor thermal environment with the help of outdoor temperature. To predict the indoor air temperature of a residential building, the regression analysis of the indoor and outdoor air temperature was conducted.

\section{Thermal Performance and Comfort Conditions Assessment (Case Studies)}

Beiruti houses were greatly influenced by the availability of stone offering the opportunity for good masonry construction. This produced families of stonemasons who passed their skills from generation to generation. Stones used were hard enough to withstand heavy loads and was used in foundations and walls. The wall coating is mainly made from lime mixed with sand and hemp that allows the wall to breathe and reduce indoor humidity. Likewise, 
tiled pyramidal shaped roofs provide efficient insulation from the heat of the sun. The construction materials and architectural design can show the efficiency of their thermal performance (Table 4). In this sense, monitoring of thermal performance of three houses was conducted by measuring air temperature and humidity in autumn, winter and spring seasons. The temperatures and humidity were measured every two months during the covered period which is from November 2016 to June 2017.

Table 4. The Characteristics of the three studied houses

\begin{tabular}{|c|c|c|c|c|}
\hline \multicolumn{2}{|c|}{ Parameters } & $\begin{array}{l}\text { Building } 1 \text { (Taweel } \\
\text { Building) }\end{array}$ & $\begin{array}{l}\text { Building } 2 \text { (OIB, Orient-Institut } \\
\text { Beirut) }\end{array}$ & $\begin{array}{l}\text { Building } 3 \text { (Hatoum } \\
\text { Building) }\end{array}$ \\
\hline \multicolumn{2}{|c|}{ Location } & Mousaytbeh & Zokak el-Blat & Ashrafiyyeh \\
\hline \multicolumn{2}{|c|}{ Building Orientation } & North & North & North \\
\hline \multicolumn{2}{|c|}{ 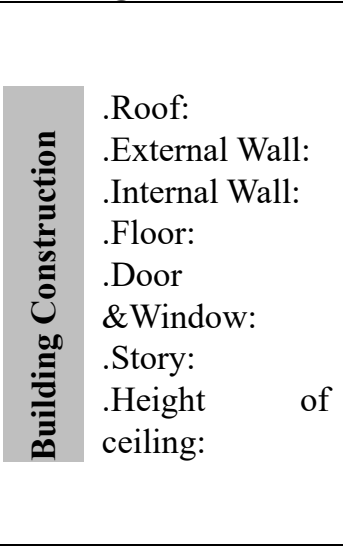 } & $\begin{array}{l}\text { Clay Tiled Pitched } \\
\text { Roof } \\
.25 \mathrm{~cm} \text { Sand stone } \\
.25 \mathrm{~cm} \text { Sand stone } \\
. \text { Lime Cement Tile } \\
\text {.Wooden Doors and } \\
\text { windows with } 8 \text { pane } \\
\text { glazing and wooden } \\
\text { shutters }+1 \text { glazed } \\
\text { Triple arcades. } \\
.2 \text { Storey } \\
.450 \mathrm{~cm}\end{array}$ & $\begin{array}{l}. \text { Flat Roof } \\
.40 \mathrm{~cm} \text { Sand stone } \\
.25 \mathrm{~cm} \text { Sand stone } \\
. \text { Lime Cement Tile } \\
. \text { Wooden Doors and windows with } \\
8 \text { pane glazing and wooden } \\
\text { shutters }+2 \text { glazed Triple arcades. } \\
.2 \text { Storey } \\
.450 \mathrm{~cm}\end{array}$ & $\begin{array}{l}\text {.Clay Tiled Pitched } \\
\text { Roof } \\
.25 \mathrm{~cm} \text { Sand stone } \\
.25 \mathrm{~cm} \text { Sand stone } \\
. \text { Lime Cement Tile } \\
\text {.Wooden Doors and } \\
\text { windows with } 8 \text { pane } \\
\text { glazing and wooden } \\
\text { shutters }+1 \\
\text { glazed } \\
\text { arcades. } \\
.1 \text { Storey } \\
.450 \mathrm{~cm}\end{array}$ \\
\hline \multicolumn{2}{|c|}{$\begin{array}{l}\text { Ventilation } \\
\text { Characteristic }\end{array}$} & $\begin{array}{l}\text { Vary open with a } \\
\text { glazed triple arcades } \\
\text { in the central hall } \\
\text { and with rectangular } \\
\text { wooden windows in } \\
\text { the other rooms. }\end{array}$ & $\begin{array}{l}\text { Vary open with a glazed triple } \\
\text { arcades in the central hall and with } \\
\text { rectangular wooden windows in } \\
\text { the other rooms. }\end{array}$ & $\begin{array}{l}\text { Vary open with a } \\
\text { glazed triple arcades } \\
\text { in the central hall and } \\
\text { with rectangular } \\
\text { wooden windows in } \\
\text { the other rooms. }\end{array}$ \\
\hline \multicolumn{2}{|c|}{ Equipment } & $\begin{array}{l}\text { Split unit usage for } \\
\text { conditioning the } \\
\text { upper room only. }\end{array}$ & $\begin{array}{l}\text { Split unit usage for } \\
\text { conditioning the house in } \\
\text { summer and winter. }\end{array}$ & $\begin{array}{lr}\text { Electricity fan used } \\
\text { during July and } \\
\text { August, Electricity } \\
\text { heater used during } \\
\begin{array}{l}\text { December } \\
\text { January and }\end{array}\end{array}$ \\
\hline
\end{tabular}

\subsection{Case study 1 (Taweel house)}

The house is located south of Beirut, Moussaytbeh quarter, and is integrated between a group of high-rise buildings (Figure 7). Its triple arcaded façade is located to the north facing a building; the east façade is recessed from the street, west and south (high-rise buildings). The building was constructed in the late nineteenth century; it consists of two stories of $4.5 \mathrm{~m}$ height and an area of $240 \mathrm{~m} 2$ each. Several bedrooms surrounding the central hall (living room) are functioning now as offices at the first floor while at the ground floor functioning as storages. The kitchen and the toilets are located to the east. The building envelope consists of bearing walls constructed by lime stone with $25 \mathrm{~cm}$ thickness with the timbered pitched red tile roof, wooden door and wooden framed single glazed windows with wooden shutters. Indoors, the walls constructed by lime stone with $25 \mathrm{~cm}$ thickness and the ceiling construction consisted of a timber frame with machine-cut beams linked to the walls. The entrance as shown on the map below is from the west having a direct access to the central hall, surrounded by four rooms and the liwan and open to the north by triple arcaded façade. During the French Mandate, new concrete balconies were added to the building as noticed in figure 9 . 


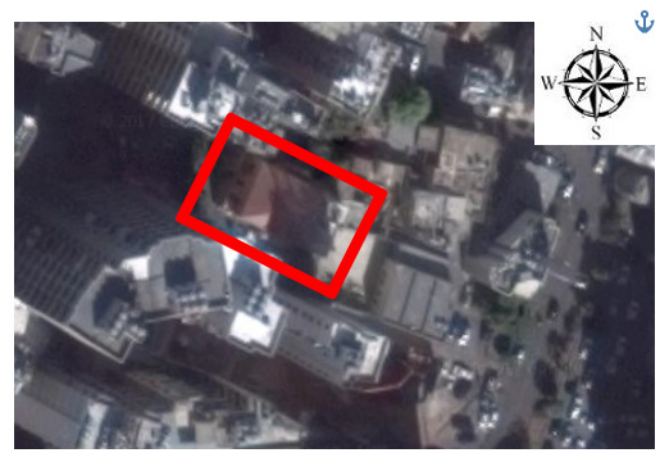

Figure 7. Taweel house surrounded by high rise building. (Google map 2017)

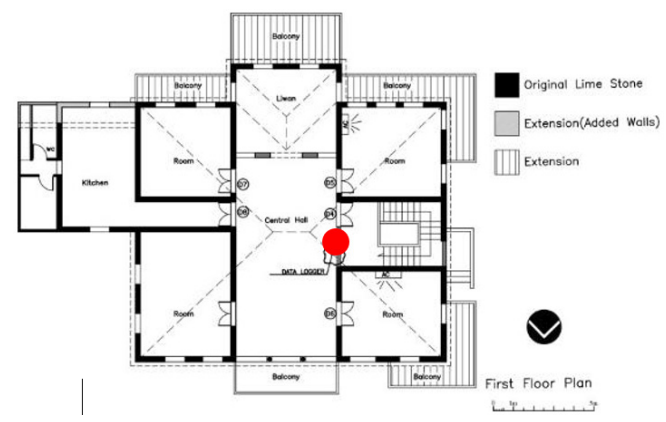

Figure 9. First floor plan, and in red is the location of the data logger, (Hammoud J., 2017)

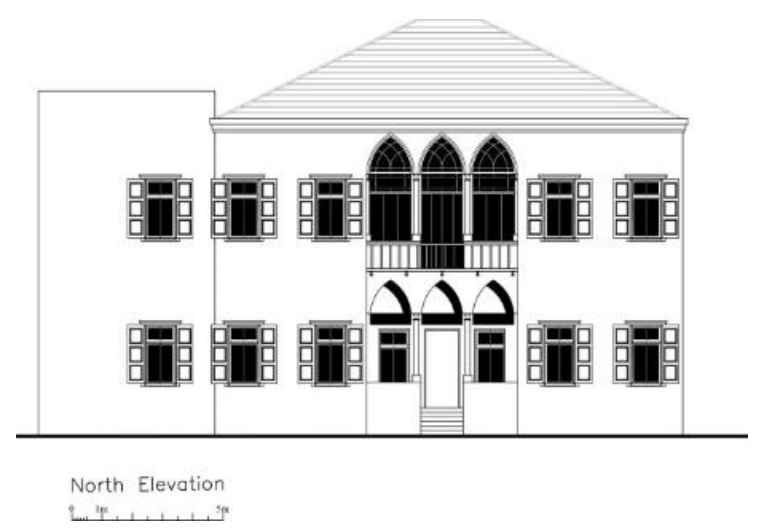

Figure 11. North elevation of Taweel house (Hammoud J., 2017)

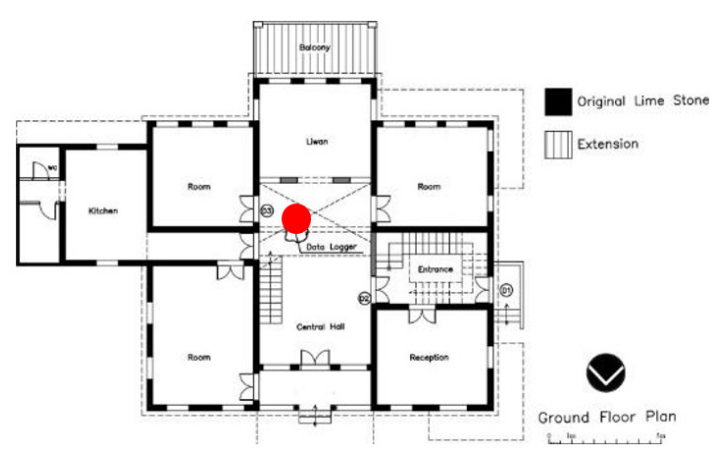

Figure 8. The ground floor plan, and in red is the location of the data logger, (Hammoud J., 2017)

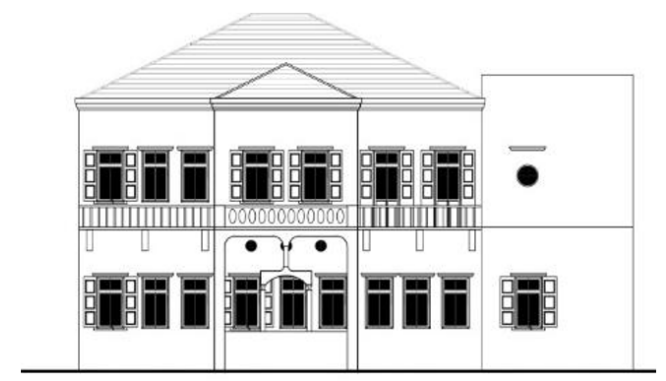

Figure 10. South elevation of Taweel house (Hammoud J., 2017)

\subsection{Case Study 2 The Orient Institute Beirut (OIB)}

The mansion is located west of Beirut, Zokak el-Blat quarter, and is integrated between a group of high-rise buildings (figure 12). The three-storey building with a symmetrically shaped façade and an elegant "piano nobile" in the second floor (figures 13\&14), dates from the mid-nineteenth century and was renovated in 1963. It was altered to be the German research center in Beirut. Its triple arcaded façade is located to the north facing a building, the east façade to an empty parcel, west (high-rise buildings) and south to open garden and a traditional building. The ground floor is characterized by thick walls and vaults with $3.4 \mathrm{~m}$ height and area. It served as stables or storage space which was altered to meeting area. The first floor with $4.5 \mathrm{~m}$ height and an area of $600 \mathrm{~m} 2$, already featured a central hall plan, with fleur-de-lis triple arched windowin the northern façade. A covered terrace running between two rooms at the southern part of the building was glazed to create an additional reading room in the 1980s. The second floor with $4.5 \mathrm{~m}$ height and an area of $600 \mathrm{~m} 2$ featured the pointed triple arched window. A conference room with additional service facilities was added on the west side of the building during 1960s as shown in the map. 
The kitchen and the toilets are located to the east. The building envelope consists of bearing walls constructed by lime stone with $40 \mathrm{~cm}$ thickness with the timbered pitched red tile roof, wooden door and wooden framed single glazed windows with wooden shutters. Indoors, the walls constructed by lime stone with $25 \mathrm{~cm}$ thickness and the ceiling construction consisted of a timber frame with machine-cut beams linked to the walls. The entrance as shown on the maps below is from the North having an indirect access to the central hall surrounded by several offices

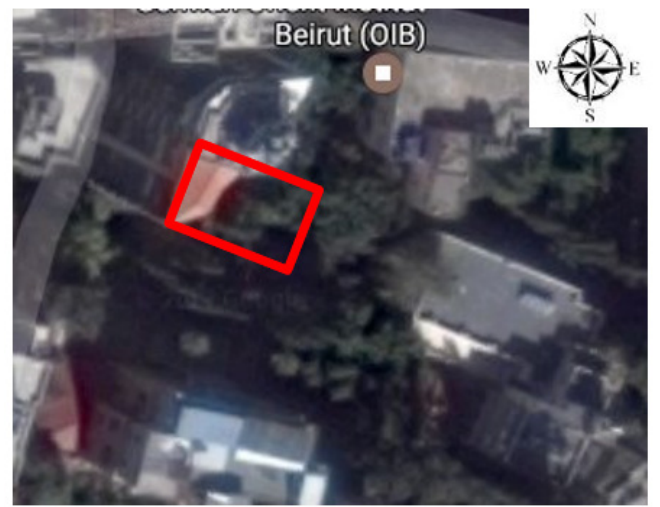

Figure 12. OIB building surrounded by high rise mansion. (Google map 2017)

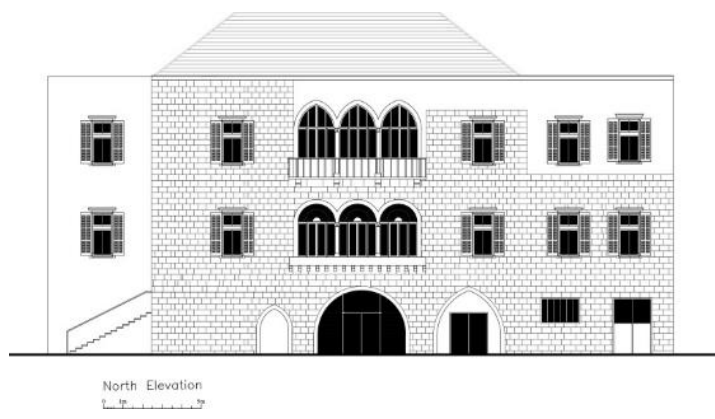

Figure 14. North Elevation of OIB mansion ( Hammoud J., 2017)

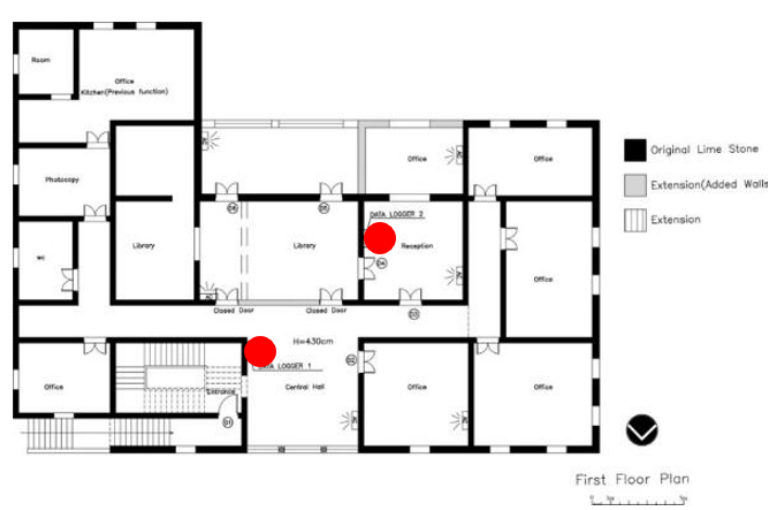

Figure 16. First floor plan. Data loggers are located in room and in the central hall as marked in red.

( Hammoud J., 2017)

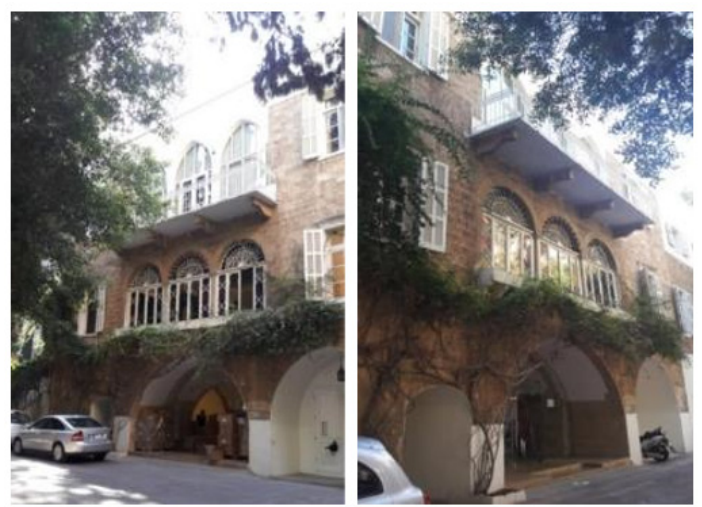

Figure 13. Main Elevation of OIB mansion ( Hammoud J., 2017)

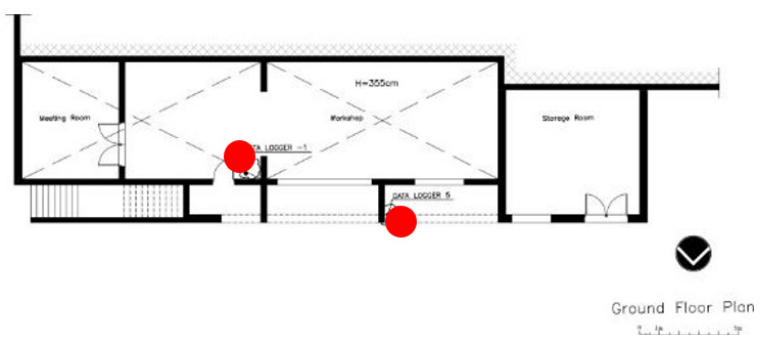

Figure 15. The ground floor plan. Data loggers are located inside and outside as marked in red.

( Hammoud J., 2017)

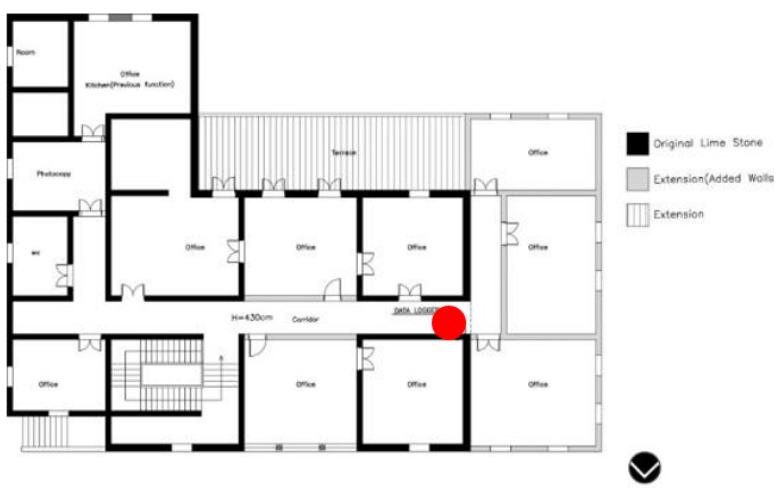

Figure 17. Second floor plan. Data logger is located at the end of the corridor as marked in red. ( Hammoud J., 2017)

\subsection{Case Study 3 (Hatoum Building)}

The building is located east of Beirut, Ashrafiyyeh quarter, and is integrated between a group of high-rise buildings (figure 18). Its triple arcaded façade located to the north and facing the main street, east (street and building), west 
and south (high-rise buildings). The building was constructed in the late nineteenth century having an area of $240 \mathrm{~m} 2$ consisting of several rooms in one story of $4.5 \mathrm{~m}$ as height. The building envelope consists of bearing walls constructed by lime stone with $25 \mathrm{~cm}$ thickness with the timbered pitched red tile roof, wooden door and wooden framed single glazed windows with wooden shutters. Indoors, the walls constructed by lime stone with $25 \mathrm{~cm}$ thickness and the ceiling construction consisted of a timber frame with machine-cut beams linked to the walls. The entrance as shown on the map below is from the east having a direct access to the central hall which is the living room, surrounded by five rooms and open to the north by triple arcaded façade. The Northern part of the building is closed and not used at all. The kitchen and the toilets are located to the west (figure 19).

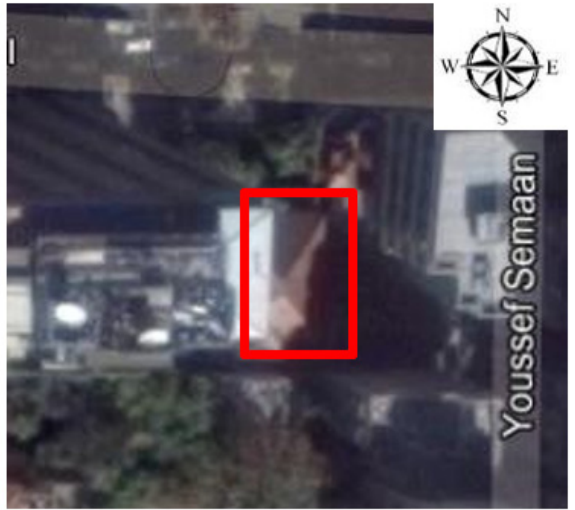

Figure 18. Location of Hatoum house(Google map 2017)

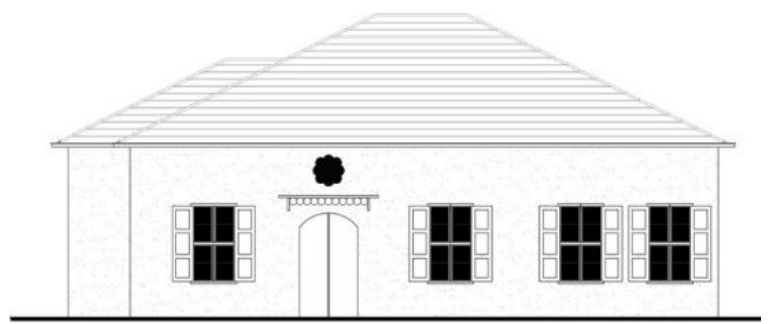

East Elevation

Figure 20. East Elevation of the Hatoum house

(Hammoud J., 2017)

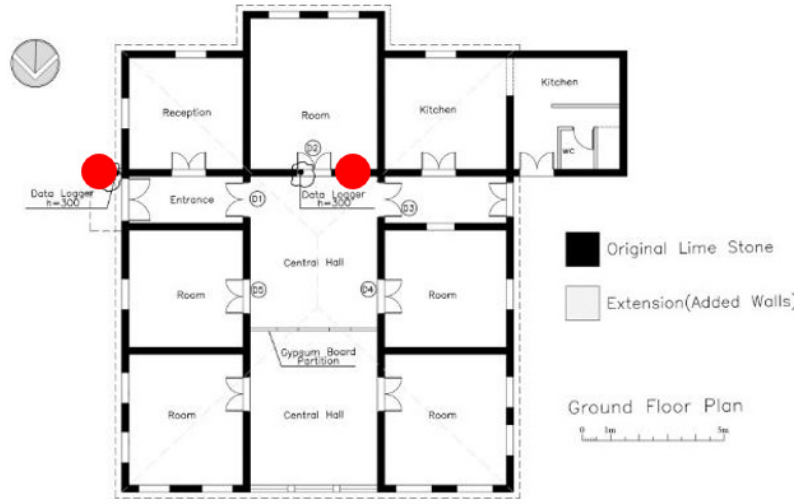

Figure 19. Ground floor plan. Data loggers are located inside and outside (Hammoud J., 2017).

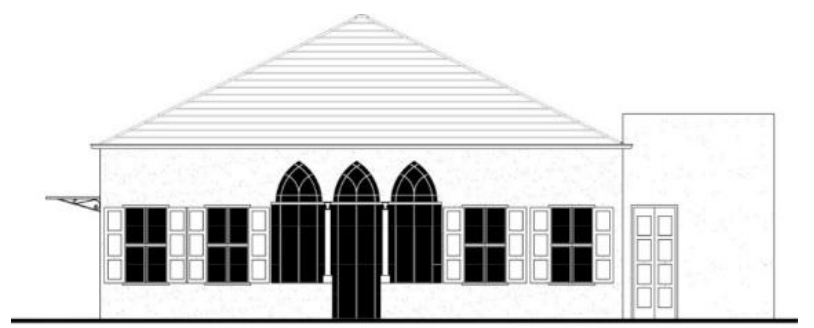

North Elevation

Figure 21. North Elevation of the Hatoum house

(Hammoud J., 2017)

\section{Hygrothermal Monitoring and Comfort Assessment}

The thermal performance monitoring was carried out between November 2016 and June 2017. The results obtained for the end of fall, winter and spring seasons in what thermal comfort is concerned are addressed and discussed. The monitoring was conducted from November 2016 to end of summer 2017.

\subsection{Case Study 1}

Monitoring during November: As for the daily circulation inside the building 1 (Taweel), that is used as private offices which open from Monday to Friday ( $8.30 \mathrm{am}$ to $4.30 \mathrm{pm})$. No Air-conditioning installed except in the two rooms at the first floor as selected in the Figures $9 \& 10$. The first floor has more circulation than the ground floor. All doors are closed except the doors named in the drawing (D1-D8). D1 is always open. D2 opens daily between $8.30 \mathrm{am}$ to $10.30 \mathrm{am}$ and then from $2.30 \mathrm{pm}$ to $4.30 \mathrm{pm}$. D3 opens several times during the day. D4, D5 and D6 open at $8.30 \mathrm{am}, 11 \mathrm{am}, 1 \mathrm{pm}$ and $4.30 \mathrm{pm}$. D7 is always open. D8 open at $11 \mathrm{am}$ and $2.30 \mathrm{pm}$ and the duration of the door opening does not exceed 5 minutes. From the analysis of the results, it is verified that during November, maximum air temperature at the ground floor was below $25.5^{\circ} \mathrm{C}$ during the monitored days and the minimum air temperature during the monitoring period was of $11.2{ }^{\circ} \mathrm{C}$ (Table5). The temperature at the central hall always shows that it increases starting $1 \mathrm{pm}$ and decreases at $12 \mathrm{am}$. The temperature is not stable; it has a thermal variation especially when compared to the upper floor. At the upper floor, the maximum temperature at the central hall was below $24.5^{\circ} \mathrm{C}$ during the monitored days and the minimum temperature is $18.5^{\circ} \mathrm{C}$ (Table 6). The central hall 
almost show a stable profile with no thermal variations compared to the ground floor. The temperature at the upper floor is $2{ }^{\circ} \mathrm{C}$ less than the ground level. This is probably due to the opening of the near doors (D $\left.4,5 \& 6\right)$ for ventilation and certainly due to the existence of the red tiled pitched roof.

Table 5. Central Hall, Ground Floor
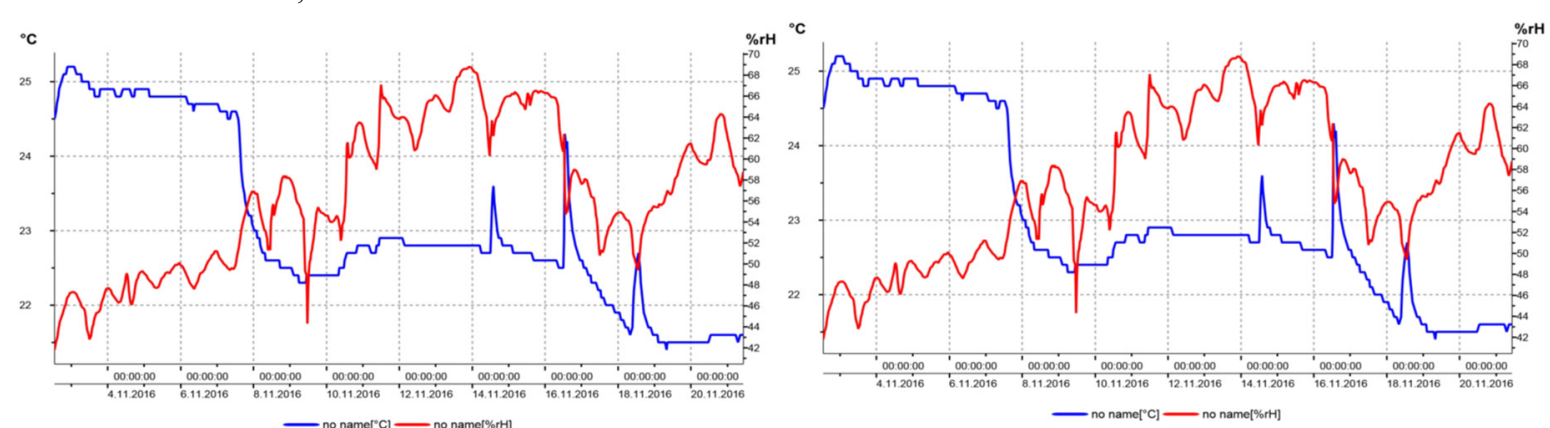

Table 6. Central Hall, First Floor

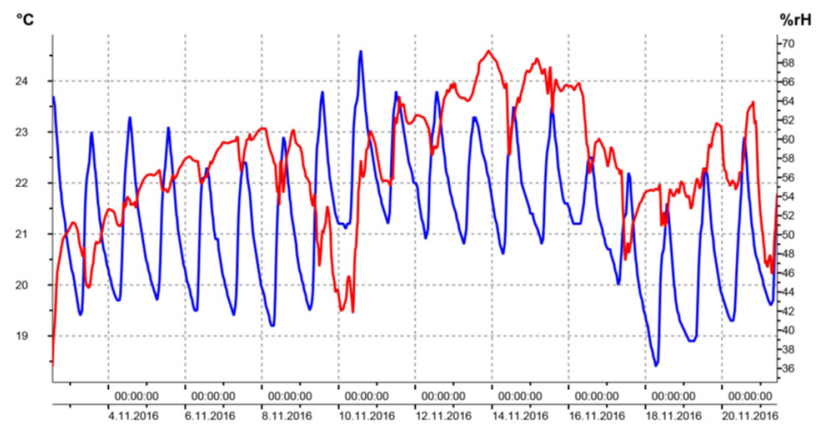

Table 7. Central Hall, Ground Floor

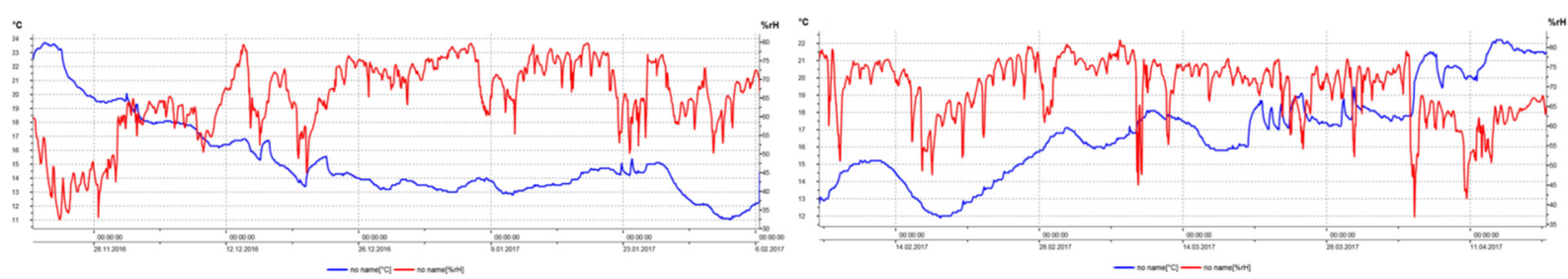

Table 8. Central Hall, Ground Floor

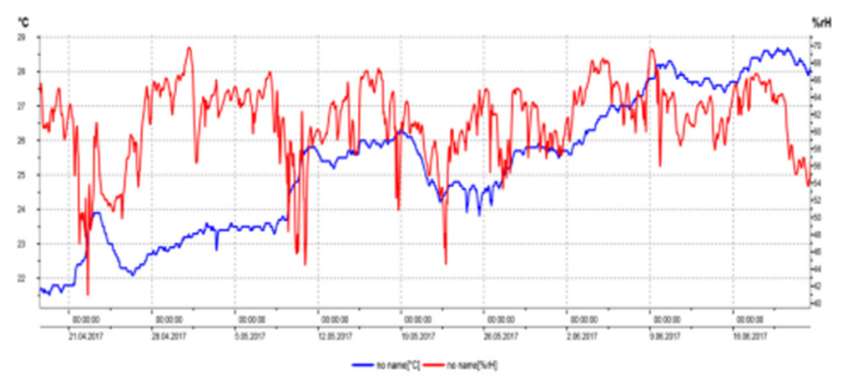

Monitoring during Winter: It is verified that during Winter, maximum air temperature at the ground floor was below $24{ }^{\circ} \mathrm{C}$ during the monitored days and the minimum air temperature during the monitoring period was of 
$13.7^{\circ} \mathrm{C}$ (Table 7). The temperature at the central hall is almost stable and shows that the difference between the highest and lowest temperature during the monitoring days is almost $10^{\circ} \mathrm{C}$ which is comfortable when compared to the human thermal comfort parameters.

Monitoring during Spring: From the analysis of the results, it is verified that during spring, maximum air temperature at the ground floor was below $25.5^{\circ} \mathrm{C}$ during the monitored days and the minimum air temperature during the monitoring period was of $11.9^{\circ} \mathrm{C}$ (Table 8). The temperature is not stable; it has a thermal variation especially when compared to winter monitoring which is not comfortable when compared to the human thermal comfort.

\subsection{Case Study 2}

The current function of the building is a research center having offices and a library which open from Monday to Friday $(8.00 \mathrm{am}$ to $5.00 \mathrm{pm})$. Air-conditioning installed in most of the rooms at the first and the second floor as selected in the drawings above except at the central hall and works all the day. The first floor has more circulation than the second floor specially the rooms having the Data Loggers as requested. In the first floor, all doors are open all the day, closed at $5 \mathrm{pm}$. Door D1 opens daily every 20 minutes and closed at $5 \mathrm{pm}$. D2 closes at $1.30 \mathrm{pm}$ and $5 \mathrm{pm}$ only. D 3 always open. Doors D4 opens every 30 minutes, closed at $5 \mathrm{pm}$. Door $5 \& 6$ closed at $5 \mathrm{pm}$ but don't have accurate time for opening, probably 2 times closed only during the day. The second floor is only offices, all doors are closed during the day, open one time at $8 \mathrm{am}, 1 \mathrm{pm}$ during the lunch break and closed at $5 \mathrm{pm}$. Data Logger is found at the Corridor where no AC s found near it. The ground floor is meeting room and space used for workshop (figure 15). Usually it is closed all the day. Rarely be used once per month. Monitoring during Winter: The monitoring was done for the central hall and the reception room at first floor. Monitoring results show that the central hall has more stable temperature profiles than the reception room. Maximum temperature recorded in both rooms are between $23.2-24.8^{\circ} \mathrm{C}$ and minimum temperature within $14.7-15.2^{\circ} \mathrm{C}$ (Table 10) being within thermal comfort range values most of time. The central hall had the most stable profile with higher temperature $\left(23.4^{\circ} \mathrm{C}\right)$ and lower temperature $\left(14.7^{\circ} \mathrm{C}\right)$. Its position in the center between rooms and the high walls, allow stabilizing temperature although there is no Air-conditioning in it and has a comfortable thermal environment, within the comfort range. The reception room shows high variations in regular periods of time (Table 11). These significant variations and temperature peaks in periods is due to the occupation profile mainly five days per week. At the upper floor (second floor), the corridor shows that the maximum temperature was $\left(26.5^{\circ} \mathrm{C}\right)$ and the minimum temperature is $\left(13.7^{\circ} \mathrm{C}\right)$ (Table 12). Compared to the first floor, the maximum temperature at the second floor is 3 degrees higher than the maximum temperature at the first floor and the minimum temperature is only 1 degree less than the first floor. At the ground floor, the temperature is almost stable, no heating system is installed at this floor, the maximum temperature was $\left(20.3^{\circ} \mathrm{C}\right)$ and the minimum $\left(15.7^{\circ} \mathrm{C}\right)$. During winter monitoring, outdoor air temperature was of $21.3^{\circ} \mathrm{C}$ (Table 13). Maximum air temperature was between $18^{\circ} \mathrm{C}-22.5^{\circ} \mathrm{C}$ most of the days, but surpassing $25^{\circ} \mathrm{C}$ on March. Minimum air temperature during the monitoring period was of $8.8^{\circ} \mathrm{C}$, but was above $10^{\circ} \mathrm{C}$ in most of the days. If we compare the temperature of indoor to outdoor, we find that at the second floor there is a lack in thermal insulation since the temperature exceed the outdoor maximum temperature.

Table 9. Ground floor: winter 2017

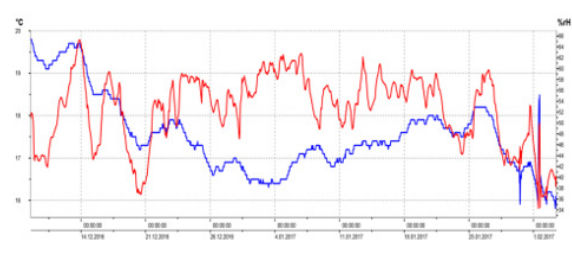

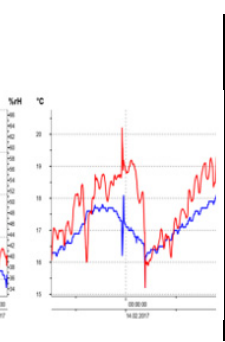

Table 10. First floor: central hall- winter 2017

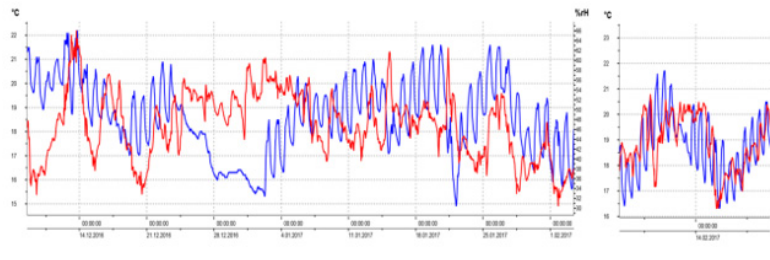

Table 11. First floor: reception room- winter 2017

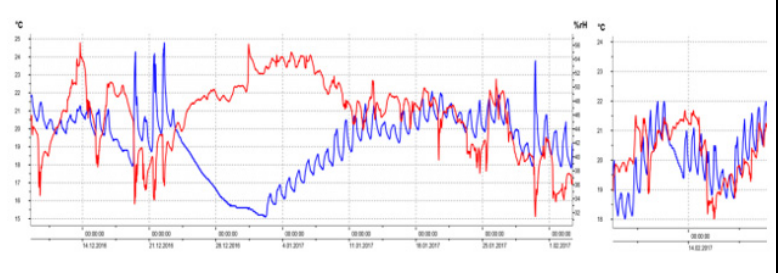

Table 12. Second floor: corridor- winter 2017

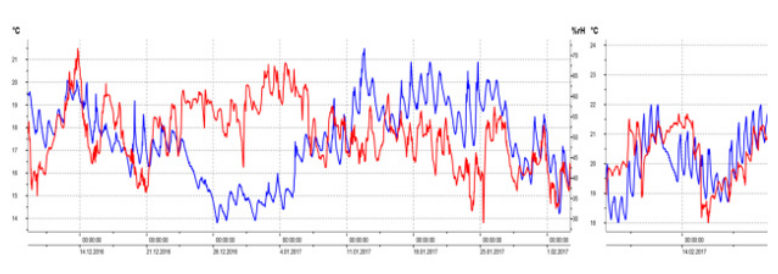


Table 13. Outside- winter 2017

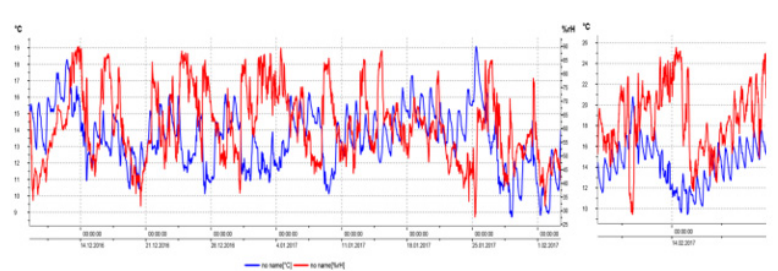

Monitoring during Summer: During summer, monitoring results show that the central hall and the reception room have stable temperature profiles. Maximum temperature recorded in both rooms is between $28.8-29.2^{\circ} \mathrm{C}$. The minimum temperature is $23.7-24.6^{\circ} \mathrm{C}$ (Table $14 \& 15$ ) being within thermal comfort range values most of time. Although the reception room has an $\mathrm{AC}$, the temperature was between $23.7-28.8^{\circ} \mathrm{C}$ and exceeded the $26^{\circ} \mathrm{C}$ during the day which is not being within the comfort range. The central hall shows 1 degree higher variations only in regular periods of time. At the upper floor (second floor), the corridor shows that the maximum temperature was $\left(33.8^{\circ} \mathrm{C}\right)$ and the minimum temperature is $\left(28.1^{\circ} \mathrm{C}\right)$ (Table 16). Compared to the first floor, the maximum temperature at the second floor is 5 degrees higher than the maximum temperature at the first floor and the minimum temperature is only 4.4 degrees less than the first floor. At the ground floor, the temperature is the most stable profile during the summer with, it shows a temperature between $22.9-27.4^{\circ} \mathrm{C}$. This maximum temperature was one day only during August while on the other days the temperature does not surpass the $26^{\circ} \mathrm{C}$ which is still within the comfort range. The outside minimum air temperature during the monitoring period was of $22.7^{\circ} \mathrm{C}$ at end of June, but was above $24^{\circ} \mathrm{C}$ in most of the days and the maximum air temperature was $32.1^{\circ} \mathrm{C}$. (Table 17). If we compare the temperature of indoor to outdoor, we find that at the second floor there is a lack in thermal insulation since the temperature exceed the outdoor maximum temperature.

Table 14. First Floor, Central Hall- Summer 2017

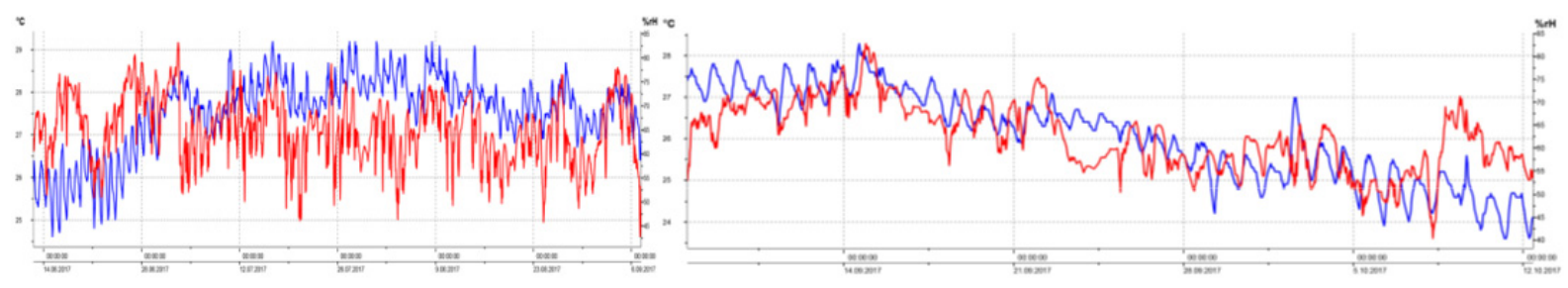

Table 15. First Floor, Reception - Summer 2017

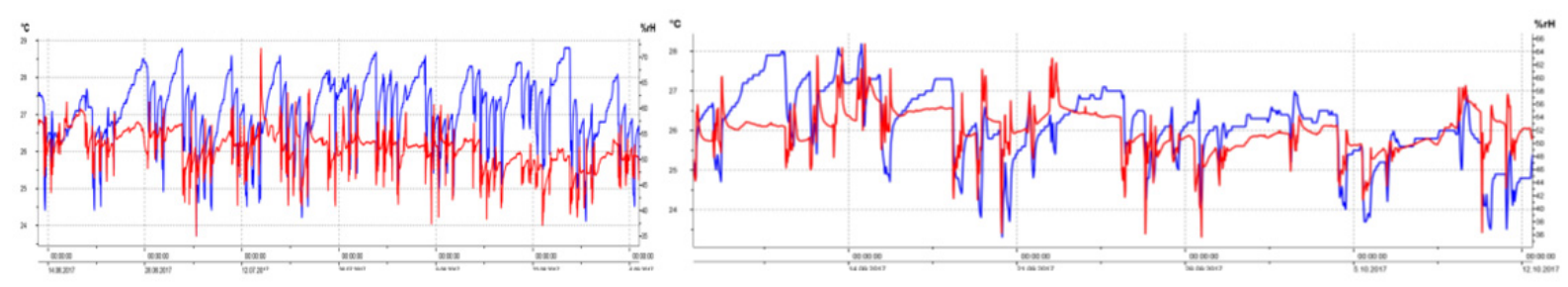

Table 16. Second Floor, Corridor - Summer 2017

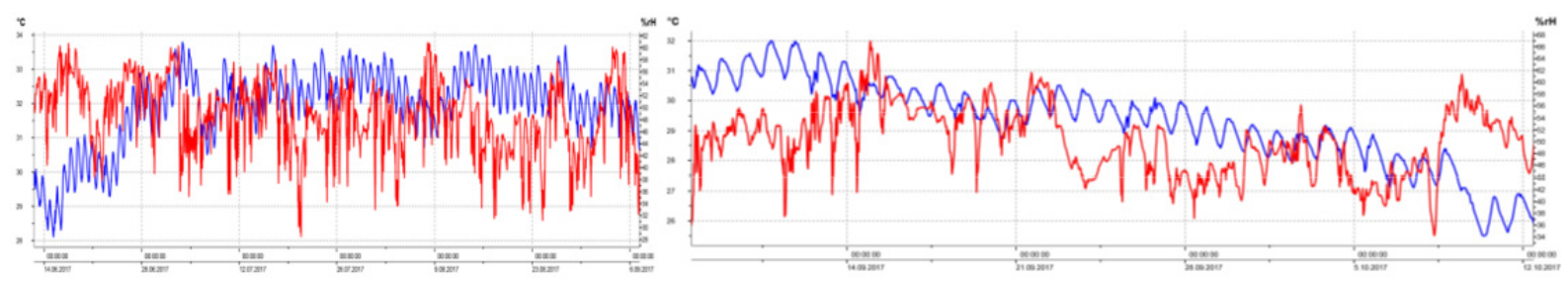


Table 17. Outside - Summer 2017

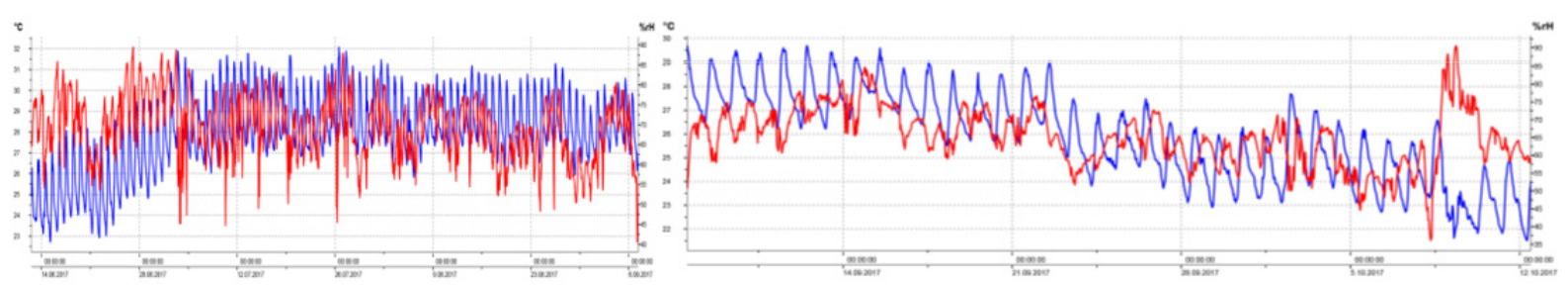

\section{Case study 3}

The current function of the building is residential. The occupants were assumed to either be at home on normal day which start from 8:00 am to 10:00 pm where occupants are active and using most of the appliances whereas the other times they are assumed to be in bed where there is no use of the energy. No Air-conditioning installed. Only portable heater is used in the central hall on December 2016 and January 2017. All doors (D2, D3, D4 \&D5) are opened during the day except when getting to sleep at $9.30 \mathrm{pm}$ the doors will be closed. D1 open twice per day, no specific time for its opening. Monitoring during Winter: The monitoring was done for the central hall. Monitoring results show that the central hall has a stable temperature profiles between $17.5-20.5^{\circ} \mathrm{C}$ and being within thermal comfort range values most of time during the day (Table 18). Maximum temperature recorded is $23.5^{\circ} \mathrm{C}$ and minimum temperature within $11.2^{\circ} \mathrm{C}$. The central hall position in the center between rooms and the high walls, allow stabilizing temperature although there is no Air-conditioning in it and has a comfortable thermal environment, within the comfort range. Maximum outdoor temperature recorded $36.4^{\circ} \mathrm{C}$ and minimum temperature within $6^{\circ} \mathrm{C}$ (Table 19). The monitoring showed that the indoor air temperature was lower than the outdoor temperature on all studied days because the building has vertical shading devices that created shadings and provided more shade and consequently decreased the indoor air temperature.

Table 19. Outside - Winter 2017
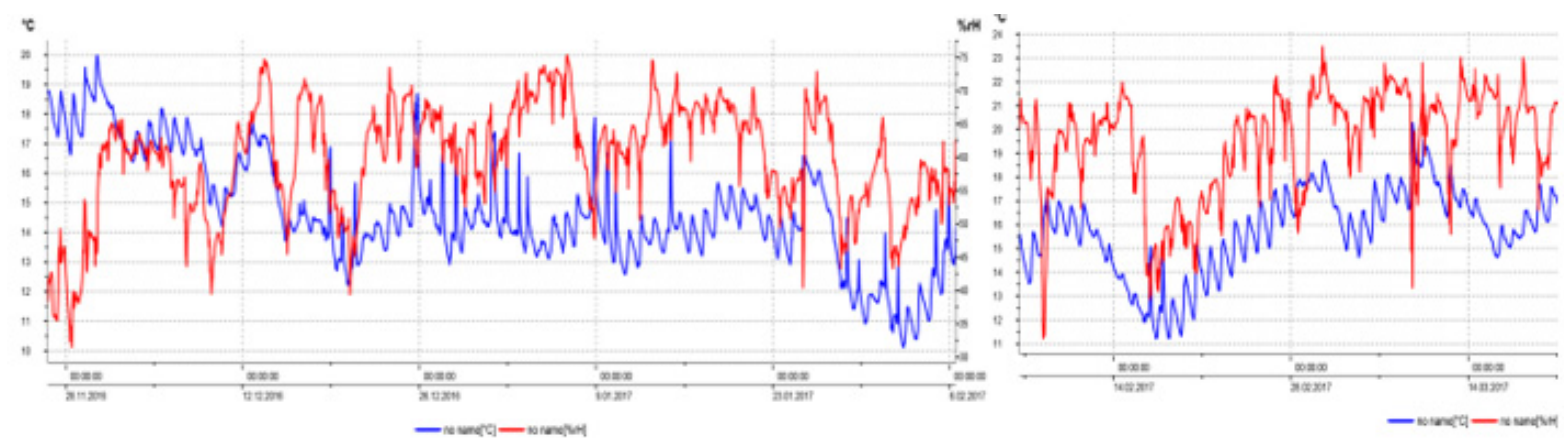

Table 18. Central Hall - Winter 2017

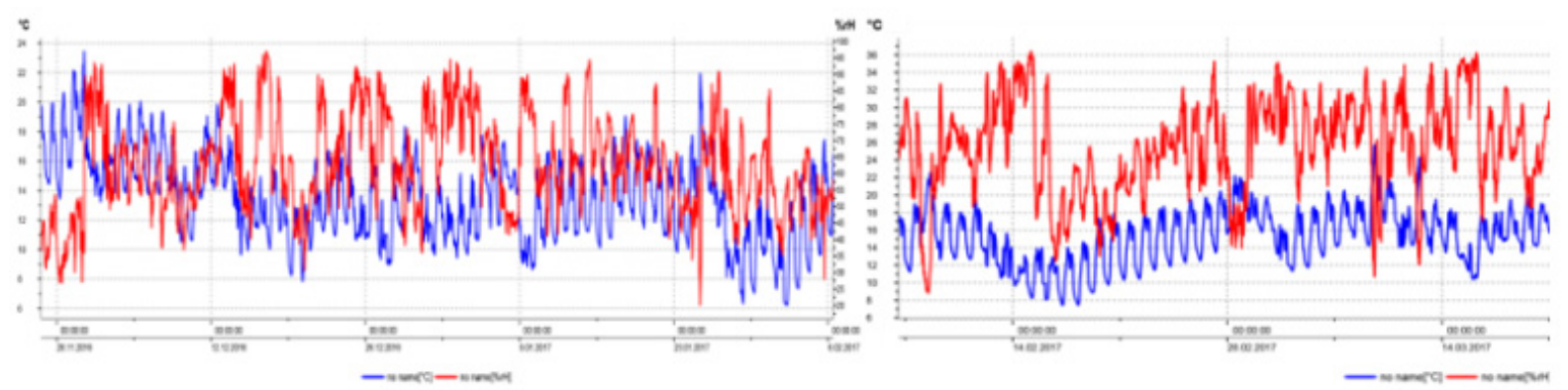

Monitoring during Summer: The monitoring was done for the central hall. Monitoring results show that the central hall has a stable temperature profiles between $27.5-31^{\circ} \mathrm{C}$ and is not being within thermal comfort range values most of time. Maximum temperature recorded in the central hall is $32^{\circ} \mathrm{C}$ and minimum temperature within $24.9^{\circ} \mathrm{C}$ 
(Table 20). Maximum outdoor temperature recorded $44 \cdot 4^{\circ} \mathrm{C}$ and minimum temperature within $22.4^{\circ} \mathrm{C}$ (Table 21). The monitoring showed that the indoor air temperature was lower than the outdoor temperature on all studied days because the building has vertical shading devices that created shadings and provided more shade and consequently decreased the indoor air temperature.

Table 20. Central Hall - Summer 2017

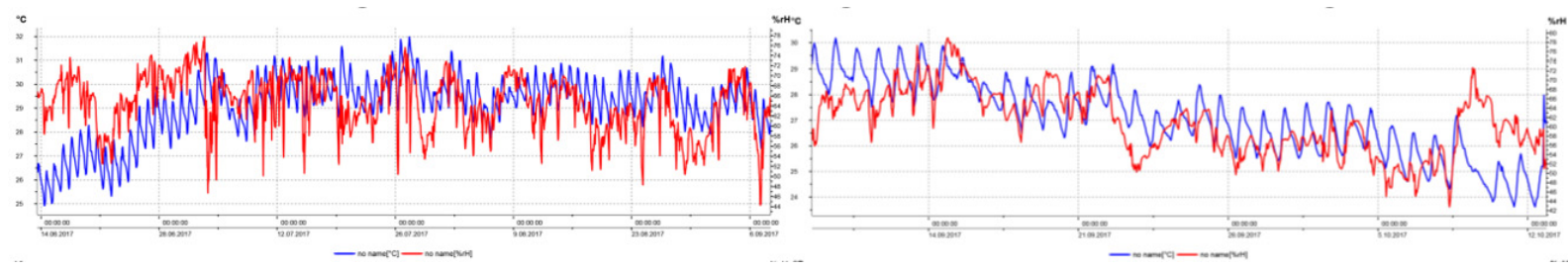

Table 21. Outside- Summer 2017
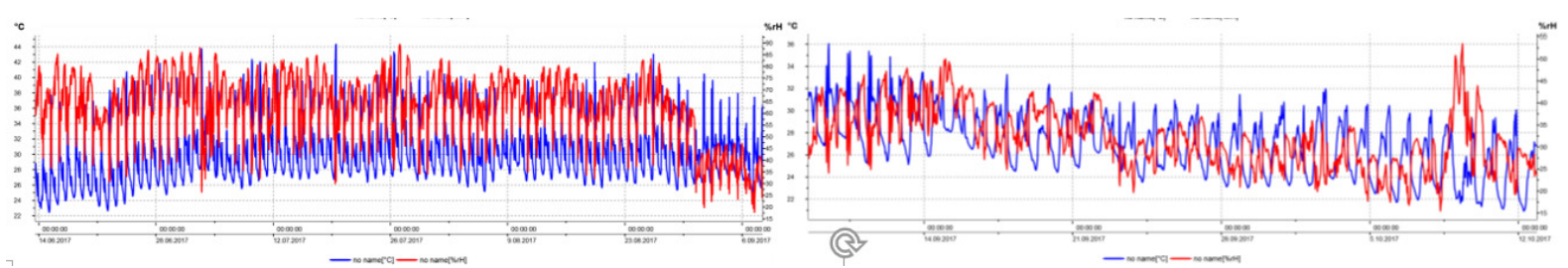

\section{Conclusion and Discussions}

The rooms that are selected for measurement and investigation are shown in Table 22. The reason for selecting these rooms is their different proximity and orientation. As shown in Table 22, the selected rooms can be divided into three categories. First, the most important room that exists in the three buildings, the central hall, that is surrounded by adjacent room and oriented to the north. Second, the reception room that is adjacent to the central hall in B2. Third, the corridor, which is in the second floor of B2 where the covering in this floor is concrete and is different from the covering of other floors constructed in the same period. Since the main purpose of this study and comparison was evaluating thermal comfort by focusing on those rooms were the most relevant choices. The reason is that they can demonstrate the pure effect on the indoor and outdoor environmental conditions. Temperature and relative humidity were measured during winter and summer. They were analyzed and summarized based on indoor and outdoor thermal environments and regional differences. Since the thermal environment can significantly affect human health (Parsons, K. 2014). Therefore, in the current study, the effect of environmental parameters, including indoor air temperature, outdoor air temperature and relative humidity on the thermal condition of houses are to be investigated and to quantify the relation between interior space temperature and climate by comparing the thermal characteristics of three Beiruti houses in summer and winter.

Table 22. Showing the temperature and humidity for different indoor spaces and outdoor. The outdoor temperature was chosen from the measurements taken from OIB building having the best temperatures complying with the Lebanese climatic zone

\begin{tabular}{|c|c|c|c|c|c|c|c|}
\hline \multirow{5}{*}{ 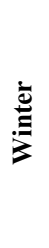 } & Building & $\begin{array}{c}\text { B1 } \\
\text { (Central Hall) }\end{array}$ & $\begin{array}{c}\text { B2 } \\
\text { (Central Hall) }\end{array}$ & $\begin{array}{c}\text { B2 } \\
\text { (Reception) }\end{array}$ & $\begin{array}{c}\text { B2 } \\
\text { (Corridor) }\end{array}$ & $\begin{array}{c}\text { B3 } \\
\text { (Central Hall) }\end{array}$ & Outside \\
\hline & Min.Temp. ${ }^{\circ} \mathrm{C}$ & 11 & 14.9 & 15.1 & 13.8 & 11.2 & 8.7 \\
\hline & Max.Temp. ${ }^{\circ} \mathbf{C}$ & 18.3 & 23.2 & 24.8 & 26.4 & 23.5 & 25.9 \\
\hline & Min.Humidity\% & 32 & 28.4 & 31.3 & 23.5 & 31.4 & 18.4 \\
\hline & Max.Humidity\% & 79.8 & 66.1 & 56.4 & 71.8 & 75.4 & 90.1 \\
\hline
\end{tabular}

Based on the winter results, the minimum indoor air temperature for all rooms were higher than the The temperature differences between inside and outside were between 2.3 and $6.5^{\circ} \mathrm{C}$ in all rooms except in the vestibule of building $\mathrm{B} 4$ where the difference surpasses $8.5^{\circ} \mathrm{C}$. The maximum indoor air temperature for all rooms were also lower than the outdoor air temperature except in the corridor of building B2 where its temperature is 
$0.5^{\circ} \mathrm{C}$ higher than outside temperature due to the concrete material used in covering which is high thermal material that stores all the energy and re radiated it into the corridor (figure 22).

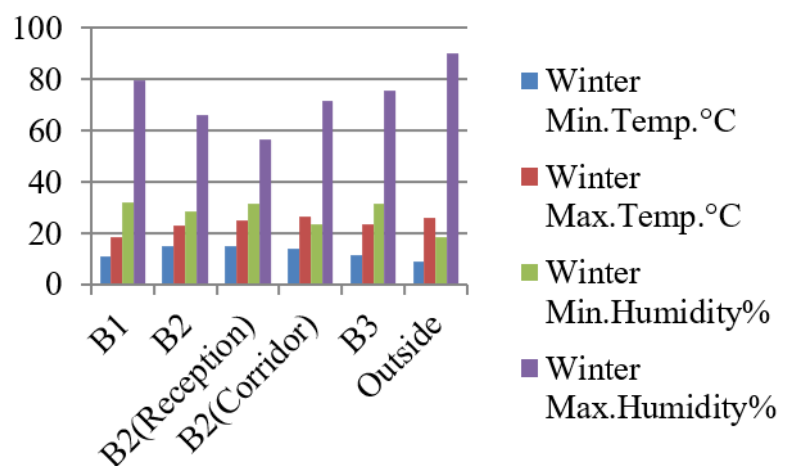

Figure 22. Temperature and Humidity measured for indoor and outdoor during winter

As for the thermal comfort condition, the winter results showed that the indoor air temperature ranged between $11^{\circ} \mathrm{C}$ and $27.1^{\circ} \mathrm{C}$ and the relative humidity did not exceed $79.9 \%$. Moreover, according to the recommendation by ASHRAE, comfort can be attained when the indoor air temperature is between $23^{\circ} \mathrm{C}$ to $29.9^{\circ} \mathrm{C}$ and the relative humidity is less than $90 \%$ in a humid climate. As shown in figure 23 , all rooms in case of minimum temperature are in the risk of thermal discomfort while in case of maximum temperature, the rooms are in the acceptable limits except the in the central hall of building B1 with no heating devices, is in the risk of thermal discomfort.

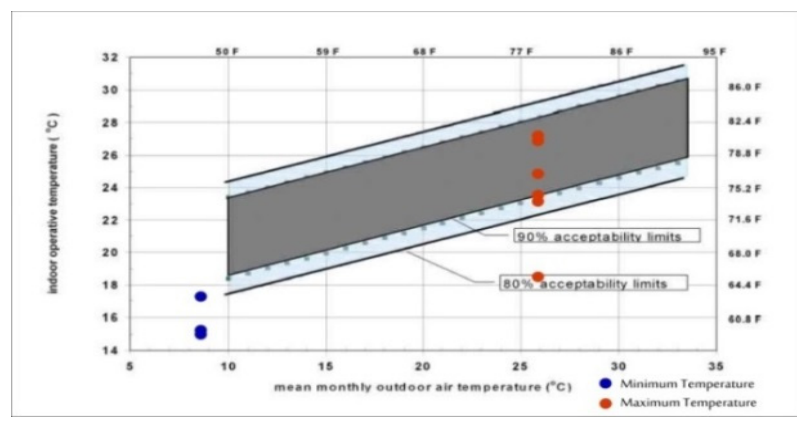

Figure 23. Acceptable operative temperature ranges for naturally conditioned spaces. (winter measurements)

Based on the summer results (table 23), the minimum indoor air temperature for all rooms were higher than the outdoor temperature. The temperature differences between inside and outside were between 1 and $2.2^{\circ} \mathrm{C}$ in all rooms except in the corridor of building B2 where the difference exceeds $5^{\circ} \mathrm{C}$ and this was due to the concrete covering for this space that lacks in thermal insulation.

Table 23. Showing the temperature and humidity for different indoor spaces and outdoor during summer.

\begin{tabular}{lccccc}
\hline \multicolumn{1}{c}{ Building } & $\begin{array}{c}\text { B2(Central } \\
\text { Hall) }\end{array}$ & $\begin{array}{c}\text { B2 } \\
\text { (Reception) }\end{array}$ & $\begin{array}{c}\text { B2 } \\
\text { (Corridor) }\end{array}$ & $\begin{array}{c}\text { B3 } \\
\text { (Central Hall) }\end{array}$ & Outside \\
\hline Min.Temp. $^{\circ} \mathbf{C}$ & 24.6 & 23.7 & 28.1 & 24.9 & 22.7 \\
Max.Temp. $^{\circ} \mathbf{C}$ & 29.2 & 28.8 & 33.8 & 32 & 32.1 \\
Min.Humidity\% $^{\text {Max.Humidity\% }}$ & 42.7 & 34.9 & 28.4 & 44.1 & 40.5 \\
\hline
\end{tabular}

It seems that the thickness of walls and the openings are not effective as thermal mass. Higher thermal mass ended up seeing high temperatures during night time. Thermal mass stores all the energy and re radiated it into the room. All the heat energy stored and it released all the energy once it is done with the storing. It is irrespective of the outside temperature. The maximum indoor air temperature for all rooms were lower than the outdoor temperature 
except in the corridor of building $\mathrm{B} 2$ where its temperature is $1.7^{\circ} \mathrm{C}$ higher than outside temperature due to the high thermal material used in its covering, the concrete. As for the thermal comfort condition, the summer results showed that the indoor air temperature ranged between $23.7^{\circ} \mathrm{C}$ and $33.8^{\circ} \mathrm{C}$ and the relative humidity did not exceed $83 \%$. Moreover, according to the recommendation by ASHRAE, comfort can be attained when the indoor air temperature is between $23^{\circ} \mathrm{C}$ to $29.9^{\circ} \mathrm{C}$ and the relative humidity is less than $90 \%$ in a humid climate. As shown in figure 25, most of the spaces are in the acceptable limits except the corridor in B2 and the central hall in B3 where there is a clear risk of thermal discomfort.

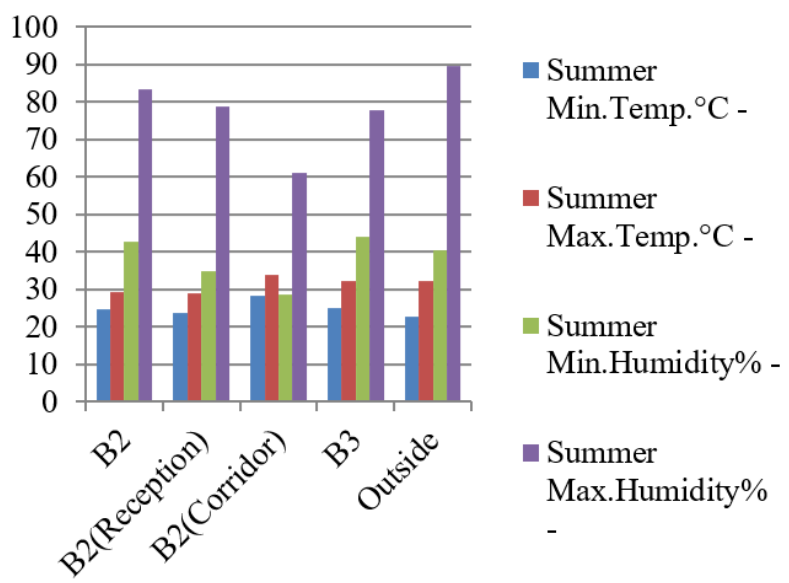

Figure 24. Temperature and Humidity measured for indoor and outdoor during summer.(summer measurements)

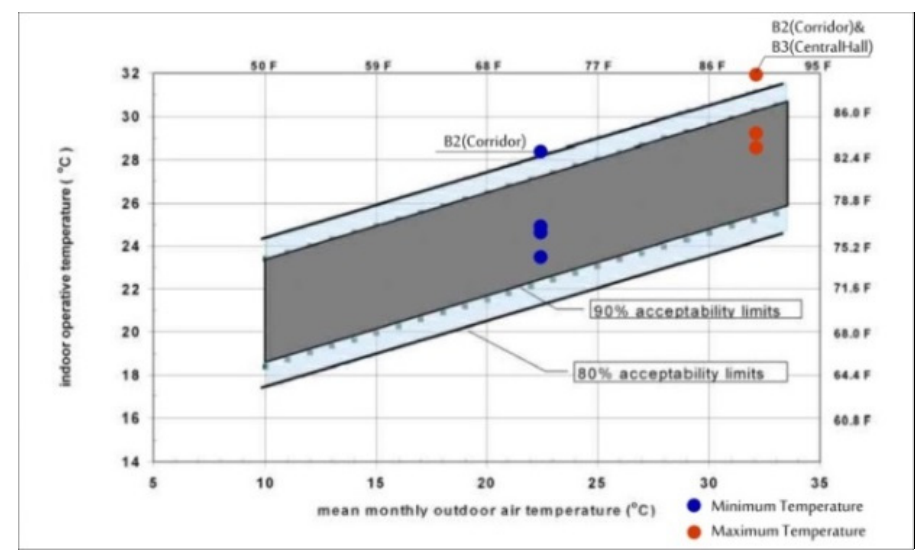

Figure 25. Acceptable operative temperature ranges for naturally conditioned spaces

This was a brief summary of the levels of thermal discomfort where the local lighting efficiency and the influence of thermal insulation materials on the exterior wall of the building can have the biggest impact on the overall efficiency of the building. In the future research, the façade will be conceived as an independent element that will deal with the envelope purely technical.

\section{References}

ASHRAE Handbook. (2013). Fundamentals (I-P ed.). American Society of Heating, Refrigerating and AirConditioning Engineers, Inc. (ASHRAE).

ASHRAE, A. S. C. (2005). 2005 ASHRAE Handbook - Fundamentals (SI). American Society of Heating, Refrigerating \& Air Conditioning.

Houri, A., \& Ibrahim-Korfali, S. (2005). Residential energy consumption patterns: The case of Lebanon. International Journal of Energy Research, 29, 755-766. https://doi.org/10.1002/er.1086

Melki, H. (2013). Windows as Environmental Modifiers in the Vernacular. In W. Weber, \& S. Yannas (Eds.), Lessons from Venacular Architecture (pp. 49-118). Routledge. ISBN-13: 978-1-88407-600-0(hbk)

Parsons, K. (2014). Human Thermal Environments: The Effects of Hot, Moderate, and Cold Environments on 
Human Health, Comfort, and Performance (3rd ed.). Boca Raton, Florida, USA: CRC Press. ISBN 9781466595996. https://doi.org/10.1201/b16750

Republic of Lebanon 2005. (2005). Thermal Standard for Buildings in Lebanon. UNDP/GEF and MPWT/DGU. Sehnaoui, N. (1981). L'occidentalisation de la vie quotidienne à Beyrouth: 1860 - 1914. Beirut: Dar An Nahar.

ASHRAE 90.1-2007. (2008). Energy Standard for Buildings Except Low-Rise Residential Buildings (I-P ed.). ASHRAE.

Holness, G. (2009, August). Energy Efficiency in Existing Buildings - Our Greatest Opportunity for a Sustainable Future, Sustaining Our Future by Rebuilding Our Past. ASHRAE Journal, 1, 1-4.

Issa-El-Khoury, G. (2015, March). Traditional Lebanese Houses: A Green Architecture. Building \& co.(9), APAVE Liban, 16-21.

Radha, C., \& Kistelegdi, I. (2016, March 26-27). Efficient Natural Ventilation in Traditional and ContemporaryHouses in Hot and Dry Climate. Proceedings of 2016 International Conference on Architecture \& Civil Engineering (ICAACE 2016). ISBN 978-xx-844xx-xx-x

\section{Copyrights}

Copyright for this article is retained by the author(s), with first publication rights granted to the journal.

This is an open-access article distributed under the terms and conditions of the Creative Commons Attribution license (http://creativecommons.org/licenses/by/4.0/). 